\title{
FAKTOR-FAKTOR YANG MEMPENGARUHI KINERJA DAN EFISIENSI BANK PERKREDITAN RAKYAT DI JAKARTA
}

\author{
Widyasari dan Nataherwin \\ Fakultas Ekonomi Universias Tarumanagara \\ Email:nawawina@yahoo.co.id
}

\begin{abstract}
This study aims to examine the influence of various factors that affect the performance and efficiency of Bank Perkreditan Rakyat (BPR). The analysis of this study is focused on the Bank Perkreditan Rakyat in Jakarta. Sample size was 72 firms-years during 2010-2012. The findings of this study show the influence of market forces, the intensity of bank loans, bank size, risk, quality of management and shareholder value simultaneously to the performance of BPR as follows for ROA was $67.51 \%$, ROE of $64.96 \%$, NII / TA amounted to $71.27 \%$. Based on the results of the regression to examine the effect of market forces, the intensity of bank loans, bank size, risk, quality of management and shareholder value simultaneously to the efficiency of the bank amounted to $82.75 \%$ of BPR. Partially LNDEPO, LOANS_TA, NIE_TA negative and significant effect, and to influence LNTA positive and significant effect on efficiency, while for variable LLP_TL and EQUITY_TA not significant.
\end{abstract}

Keywords: Bank Perkreditan Rakyat, Performance, efficiency.

\begin{abstract}
Abstrak: Penelitian ini bertujuan untuk menguji pengaruh berbagai faktor yang mempengaruhi kinerja dan efisiensi Bank Perkreditan Rakyat (BPR). Analisis penelitian ini difokuskan pada Bank Perkreditan Rakyat di Jakarta. Ukuran sampel adalah 72 perusahaan-tahun selama 2010-2012. Temuan penelitian ini menunjukkan pengaruh kekuatan pasar, intensitas pinjaman bank, ukuran Bank, risiko, kualitas manajemen dan nilai pemegang saham secara simultan terhadap kinerja BPR sebagai berikut untuk ROA adalah 67,51\%, ROE dari 64,96\%, NII / TA sebesar 71,27\%. Berdasarkan hasil regresi untuk menguji pengaruh kekuatan pasar, intensitas pinjaman bank, ukuran Bank, risiko, kualitas manajemen dan nilai pemegang saham secara bersamaan untuk efisiensi bank sebesar 82,75\% dari BPR. Sebagian LNDEPO, LOANS_TA, NIE_TA efek negatif dan signifikan, dan untuk mempengaruhi LNTA berpengaruh positif dan signifikan pada efisiensi, sedangkan untuk variabel LLP_TL dan EQUITY_TA tidak signifikan.
\end{abstract}

Kata kunci: Bank Perkreditan Rakyat, Kinerja, efisiensi.

\section{PENDAHULUAN}

Bank Perkreditan Rakyat (BPR) sebagai salah satu jenis bank yang dikenal melayani golongan pengusaha mikro, kecil dan menengah dengan lokasi yang pada umumnya dekat dengan tempat masyarakat yang membutuhkan. BPR khusus melayani keperluan masyarakat di wilayah pedesaan dan usaha mikro kecil (UMK) dalam bentuk simpanan (tabungan dan deposito) dan kredit. BPR tidak dapat menerbitkan cek dan bilyet giro seperti bank umum. Wilayah operasional BPR terbatas hanya dalam lingkup satu propinsi. Oleh karena itu kajian dalam penelitian ini akan mendukung program pengembangan 
UMKM dengan melihat performa BPR menjalan fungsi intermediasi keuangan. Untuk dapat bersaing dalam industri perbankan, BPR dalam menjalankan usahanya harus lebih efisien dan efektif. Oleh karena itu, diperlukan suatu BPR yang sehat, kuat, dan terpercaya dimana BPR perlu meningkatkan kinerja perusahaannya. Dalam penelitian ini, peneliti tertarik untuk mengetahui berbagai faktor yang yang mempengaruhi kinerja Bank BPR serta faktor yang mempengaruhi efisiensi Bank BPR. Memang berbagai faktor makro ekonomi yang kurang baik dapat mempengaruhi kinerja. Pencapaian kinerja yang baik diperlukan suatu pendekatan dimana terciptanya suatu keberlangsungan Bank BPR yang dapat meningkatkan efisiensi.

Penelitian ini bertujuan untuk mengetahui pengaruh faktor-faktor yang mempengaruhi kinerja dan efisiensi Bank Perkreditan Rakyat. Sedangkan Manfaat Penelitian untuk memberi konfirmasi, dukungan, tanggapan terhadap hasil penelitian terdahulu, membantu dalam memberikan pertimbangan-pertimbangan mengenai aturan perbankan, termasuk apakah Bank Indonesia memberikan perlindungan kepada nasabah / masyarakat. Hasil penelitian ini diharapkan dapat dijadikan salah satu pedoman untuk penyempurnaan peraturan dan kebijakan perusahaan dan diharapkan dapat menjadi informasi dalam pengambilan keputusan investasi di perbankan.

\section{KAJIA TEORI}

Kinerja Perbankan dapat diartikan sebagai ukuran tingkat keberhasilan manajemen dalam mengelola sumber daya perusahaan, baik sumber daya financial maupun non financial. Kinerja juga menyangkut aspek akuntabilitas publik, transparansi alokasi dan pemanfaatan sumber daya, serta tata kelola perusahaan yang baik. Rasio-Rasio keuangan yang termasuk dalam CAMEL dapat digunakan sebagai alat ukur kinerja perbankan. CAMEL adalah aspek yang paling banyak berpengaruh terhadap kondisi keuangan bank yang mempengaruhi pula tingkat kesehatan bank. CAMEL merupakan tolak yang menjadi obyek pemeriksaaan bank yang dilakukan oleh pengawas bank. CAMEL terdiri atas lima kriteria yaitu modal, aktiva, manajemen, pendapatan, dan likuiditas. Berikut ini rasio-rasio yang terdapat pada CAMEL yaitu: (a) CAR (Capital Adequancy Ratio) adalah rasio yang memperlihatkan seberapa besar jumlah seluruh aktiva bank yang mengandung risiko (kredit, penyertaan, surat berharga, tagihan pada bank lain) ikut dibiayai dari modal sendiri disamping memperoleh dana-dana dari sumber-sumber diluar bank; (b) Rasio Aktiva Tetap terhadap Modal (ATTM) adalah rasio yang mengukur kemampuan manajemen bank dalam menentukan besarnya aktiva tetap dan inventaris yang dimiliki bank yang bersangkutan terhadap modal; (c) Rasio Aktiva Produktif Bermasalah (APB) adalah rasio yang menunjukkan kemampuan manajemen bank dalam mengelola aktiva produktif bermasalah terhadap total aktiva produktif; (d) NPL (Non Performing Loan) adalah rasio yang menunjukkan bahwa kemampuan manajemen bank dalam mengelola kredit bermasalah yang diberikan oleh bank; (e) Rasio PPAPAP (Penyisihan Penghapusan Aktiva Produktif terhada Aktiva Produktif) adalah rasio yang menunjukkan kemampuan manajemen bank dalam menjaga kualitas aktiva produktif sehingga jumlah PPAP dapat dikelola dengan baik; (f) Rasio pemenuhan PPAP adalah rasio yang menunjukkan kemampuan manajemen bank dalam menentukan besarnya PPAP yang telah dibentuk terhadap PPAP yang wajib dibentuk; (g) ROA (Return on Assets) adalah rasio yang digunakan untuk mengukur kemampuan manajemen bank dalam memperoleh keuntungan yang dihasilkan dari rata-rata total asset bank yang bersangkutan; (h) ROE (Return on 
Equity) adalah rasio yang digunakan untuk mengukur kinerja manajemen bank dalam mengelola modal yang tersedia untuk menghasilkan laba setelah pajak; (i) NIM (Net Interest Margin) adalah rasio yang digunakan untuk mengukur kemampuan manajemen bank dalam mengelola aktiva produktifnya untuk menghasilkan pendapatan bunga bersih; (j) BOPO (Rasio Biaya Operasional terhadap Pendapatan Operasional) adalah rasio yang sering disebut rasio efisiensi ini digunkana untuk mengukur kemampuan manajemen bank dalam mengendalikan biaya operasional terhadap pendapatan operasional; (k) LDR (Loan to Deposit Ratio) adalah rasio yang digunakan untuk menilai likuiditas suatu bank yang dengan cara membagi jumlah kredit yang diberikan oleh bank terhadap dana pihak ketiga.

Efisiensi Perbankan adalah salah satu parameter pengukuran kinerja lainnya yang cukup populer dalam dunia perbankan, dimana efisiensi merupakan suatu konsep yang secara umum telah digunakan dalam mengukur kinerja suatu perusahaan. Penelitian ini menggunakan model Data Envelopment Analysis (Coelli, Prasada-Rao, dan Battese, 1998). Model ini diperkenalkan suatu ukuran efisiensi untuk masing-masing decision making unit (DMU) yang merupakan rasio maksimum antara output yang terbobot dengan input yang terbobot. Jika DMU yang terletak di perbatasan, ini disebut sebagai unit yang efisien, jika tidak diberi label sebagai tidak efisien. Data diselimuti sedemikian rupa sehingga jarak radial perbatasan diminimalkan. Dalam prakteknya, nilai efisiensi dihitung dengan memecahkan masalah pemrograman linier. Analisis bawah DEA berkaitan dengan pemahaman bagaimana setiap DMU kinerja relatif terhadap orang lain, penyebab inefisiensi, dan bagaimana DMU yang dapat meningkatkan kinerja untuk menjadi efisien. Dalam arti bahwa, DEA menghitung efisiensi relatif setiap DMU dalam hubungannya dengan semua DMU lain dengan menggunakan nilai yang diamati sebenarnya untuk input dan output dari setiap DMU. Hal ini juga mengidentifikasi, untuk DMU yang tidak efisien, sumber dan tingkat inefisiensi untuk masing-masing input dan output. DEA ini dilakukan dengan asumsi baik constant returns to scale (CRS) atau variable returns to scale (VRS). Estimasi dengan dua asumsi memungkinkan efisiensi teknis keseluruhan (TE) untuk didekomposisi menjadi dua komponen kolektif lengkap: murni teknis (PTE) dan skala efisiensi (SE) yaitu TE = PTE x SE. Pertama, berkaitan dengan kemampuan manajer untuk memanfaatkan perusahaan "sumber daya yang diberikan, sedangkan yang kedua mengacu memanfaatkan skala ekonomi dengan beroperasi pada suatu titik di mana perbatasan produksi pameran skala pengembalian konstan. Sebuah fitur yang berguna dari model VRS dibandingkan dengan model CRS bahwa laporan apakah unit pengambilan keputusan (DMU) beroperasi pada peningkatan, konstan atau menurun atas skala. Skala hasil konstan akan berlaku ketika CRS dan efisiensi perbatasan VRS adalah tangensial satu sama lain, dengan kata lain, ketika kemiringan perbatasan efisiensi sama dengan rasio input ke output (Cooper et al, 2000.). Meningkat atas skala harus mengajukan permohonan di bawah level tersebut, karena kemiringan batas efisien, yang mencerminkan tingkat transformasi marjinal dari input ke output) akan lebih besar dari rata-rata tingkat konversi. Demikian juga, menurun kembali ke skala harus mengajukan permohonan atas zona di mana skala hasil konstan berlaku. DMU tidak di perbatasan yang efisien pertama harus diproyeksikan ke tapal batas efisien sebelum kembali mereka dengan status skala dapat dinilai.

\section{Hipotesis}

$\mathrm{H}_{1}$ : Kekuatan pasar, intesitas pinjaman bank, ukuran bank, risiko, kualitas manajemen dan nilai pemegang saham berpengaruh terhadap kinerja perbankan 
$\mathrm{H}_{2}$ : Kekuatan pasar, intesitas pinjaman bank, ukuran bank, risiko, kualitas manajemen dan nilai pemegang saham berpengaruh terhadap efisiensi

\section{METODE}

Penelitian ini dikategorikan sebagai hypotheses testing. Populasi penelitian ini adalah bank-bank perkreditan rakyat yang beroperasi di DKI Jakarta selama tahun 20102012. Sampel diambil berdasarkan purposive sampling yaitu bank-bank perkreditan rakyat yang terdaftar selama tahun observasi dan memiliki data laporan keuangan yang lengkap. Variabel dependen dalam penelitian ini adalah kinerja (performance), efficiency. Sedangkan variabel independen dalam penelitian ini adalah Kekuatan pasar, intesitas pinjaman bank, ukuran bank, risiko, kualitas manajemen dan nilai pemegang saham.

Variabel Performance adalah ukuran tingkat keberhasilan manajemen dalam mengelola sumber daya perusahaan, baik sumber daya finansial maupun non finansial. Pada penelitian ini, kami menggunakan pengukuran finansial untuk menilai kinerja perusahaan, yaitu ROA (return on total assets), ROE (return on equity), net interest income to total assets (NII/TA). Variabel Efficiency adalah tingkat seberapa banyak pemanfaatan total aset untuk mencapai keuntungan menggunakan DEA. Kedua inputoriented (IOM) dan berorientasi keluaran (OOM) versi dari metodologi DEA telah diterapkan pada data demi efisiensi skor perbandingan. Sebuah model berorientasi keluaran menyiratkan bahwa efisiensi diperkirakan oleh output dari perusahaan relatif terhadap tingkat praktek terbaik output untuk tingkat input. Untuk menentukan formulasi matematis dari OOM ini, mari kita asumsikan bahwa kita memiliki Keputusan K membuat unit (DMU) 7 menggunakan $\mathrm{N}$ input untuk menghasilkan output $\mathrm{M}$. Input dinotasikan dengan xjk $(\mathrm{j}=1$, Oo, $\mathrm{n})$ dan output yang diwakili oleh yik $(\mathrm{i}=1, \mathrm{o} . ., \mathrm{m})$ untuk setiapLKM k (k=1, o .., K). Efisiensi DMU dapat diukur sebagai (Coelli, 1998). Variabel Kekuatan Pasar adalah untuk mengukur kekuatan pasar, LNDEPO, diukur dengan deposito bank dibagi dengan total aset. Variabel Intensitas Pinjaman Bank adalah pengukuran intesitas pinjaman bank, LOANS_TA, mengungkapkan hubungan positif dan signifikan terhadap efisiensi dan kinerja. Variabel Ukuran Bank adalah proksi dari ukuran bank (LNTA) untuk menangkap keuntungan biaya yang mungkin terkait dengan ukuran (skala ekonomi). Variabel Risiko diukur menggunakan rasio LLP_TL yaitu provisi kerugian pinjaman dibagi dengan total pinjaman. Variabel Kualitas Manajemen adalah rasio biaya operasi non bunga terhadap total aset, NIE (Non interest expense) /TA, digunakan untuk memberikan informasi tentang variasi dalam biaya operasi seluruh sistem perbankan. Variabel Nilai pemegang Saham adalah diukur dengan menggunakan rasio EQUITY/TA, yaitu nilai buku ekuitas dibagi total aset.

Model Penelitian yang digunakan untuk menguji hipotesis digunakan analisis regresi linear berganda dengan menggunakan eviews 6 , model penelitian adalah:

1. Kinerja

$$
\begin{aligned}
\mathrm{ROA}= & \alpha 1+\alpha 2 \text { LNDEPO }+\alpha 3 \text { LOANS_TA }+\alpha 4 \text { LLP_TL }+\alpha 5 \text { NIE_TA }+\alpha 6 \\
& \text { EQUITY_TA }+\alpha 7 \text { LNTA }+\varepsilon \\
\text { ROE }= & \alpha 1+\alpha 2 \text { LNDEPO }+\alpha 3 \text { LOANS_TA }+\alpha 4 \text { LLP_TL }+\alpha 5 \text { NIE_TA }+\alpha 6 \\
& \text { EQUITY_TA }+\alpha 7 \text { LNTA }+\varepsilon \\
\text { NII/TA }= & \alpha 1+\alpha 2 \text { LNDEPO }+\alpha 3 \text { LOANS_TA }+\alpha 4 \text { LLP_TL }+\alpha 5 \text { NIE_TA }+\alpha 6 \\
& \text { EQUITY_TA }+\alpha 7 \text { LNTA }+\varepsilon
\end{aligned}
$$


2. Efisiensi

$$
\begin{gathered}
\text { DEA }=\alpha 1+\alpha 2 \text { LNDEPO }+\alpha 3 \text { LOANS_TA }+\alpha 4 \text { LLP_TL }+\alpha 5 \text { NIE_TA }+\alpha 6 \\
\text { EQUITY_TA }+\alpha 7 \text { LNTA }+\varepsilon
\end{gathered}
$$

\section{HASIL DAN PEMBAHASAN}

Selama tahun 2010-2012 jumlah populasi Bank Perkreditan Rakyat sebanyak 75 firmyears. Karena datanya tidak lengkap, maka data yang dikeluarkan sebanyak 3 firm-years, sehingga total sampel yang digunakan dalam mengolah penelitian ini menjadi 72 firmsyears. Berikut tabel analisis deskriptif atas variabel yang diteliti.

Tabel 1. Statistik Deskriptif Hasil Penelitian

\begin{tabular}{lrrrrr}
\hline & \multicolumn{1}{c}{ ROA } & \multicolumn{1}{c}{ ROE } & NII/TA & \multicolumn{1}{c}{ DEA } & \multicolumn{1}{c}{ LNDEPO } \\
\hline Mean & 0.014444 & 0.051417 & 0.156557 & 0.713801 & 0.531721 \\
Median & 0.017 & 0.04 & 0.1499 & 0.6926 & 0.66569 \\
Maximum & 0.222 & 1 & 0.2706 & 1 & 0.922673 \\
Minimum & -0.291 & -0.24 & 0.0074 & 0.2525 & 0.030498 \\
Std. Dev. & 0.065324 & 0.143598 & 0.05263 & 0.227881 & 0.297769 \\
Observations & 72 & 72 & 72 & 72 & 72 \\
& LOANS_TA & LLP_TL & NIE_TA & EQUITY_TA & \multicolumn{1}{c}{ LNTA } \\
Mean & 0.6868 & 0.0157 & 0.1192 & 0.3146 & 17.1856 \\
Median & 0.7224 & 0.0109 & 0.1080 & 0.1931 & 17.2967 \\
Maximum & 0.9703 & 0.2623 & 0.3030 & 0.9233 & 19.3809 \\
Minimum & 0.0034 & 0.0001 & 0.0460 & -0.0057 & 14.8756 \\
Std. Dev. & 0.1960 & 0.0312 & 0.0507 & 0.2802 & 1.1392 \\
& & & & & 72 \\
Observations & 72 & 72 & 72 & & 72 \\
\hline
\end{tabular}

Berdasarkan Tabel 1 variabel kekuatan pasar (LNDEPO) yang diukur dengan deposito, hal ini menunjukkan sebagian besar bank BPR mendapatkan dana dari deposito.Variabel LOANS_TA menunjukkan bahwa bank BPR memberikan kredit yang cukup tinggi bila dibandingkan antar bank aktiva. Variabel risiko yang diukur dengan rasio provisi kerugian pinjaman menunjukkan rata-rata provisi kerugian yang dialami bank BPR masih kecil. Rasio biaya operasi non bunga (NIE_TA) menunjukkan nilai ratarata yang rendah. Nilai rasio ekuitas terhadap total aset menunjukkan bahwa ada bank BPR yang masih mendapatkan sumber dana utamanya dari pemegang sahamnya. Untuk variabel kinerja keuangan rata-rata ROE dan ROA yang tergolong masih rendah, hal ini membuktikkan bahwa bank BPR di Jakarta sebagian besar belum mencapai kinerja keuangan yang baik. Sedangkan nilai efisiensinya rata-rata sebesar 0,71, hal ini menunjukkan efisiensi bank BPR di Jakarta menunjukkan efisiensi yang tinggi. Uji Diagnostik ini dilakukan untuk mengetahui apakah model estimasi telah memenuhi kriteria ekonometrika, dalam arti tidak terjadi penyimpangan yang cukup serius dari asumsi-asumsi yang harus dipenuhi dalam metode Ordinary Least Square (OLS) (Gujarati dan Down, 2009). 
Pengujian normalitas menurut Nachrowi dan Hardius (2006) dimaksudkan untuk mendeteksi apakah data yang akan digunakan sebagai pangkal tolak pengujian hipotesis merupakan data empirik yang memenuhi hakikat naturalistik. Hakikat naturalistik menganut faham bahwa penomena (gejala) yang terjadi di alam ini berlangsung secara wajar dan dengan kecenderungan berpola. Hasil uji Jarque-Bera menurut (Nachrowi dan Hardius, 2006) dengan hipotesis pengujian sebagai berikut:

Ho: Sampel berasal dari populasi berdistribusi normal.

H1: Sampel berasal dari populasi berdistribusi tidak normal.

Untuk mengetahui normalitas hasil residual menunjukkan hasil nilai dibawah 5\% (p-value $=0.00$ ), maka H0 ditolak yaitu data berdistribusi tidak normal. yang disajikan pada gambar dibawah ini.

Model 1

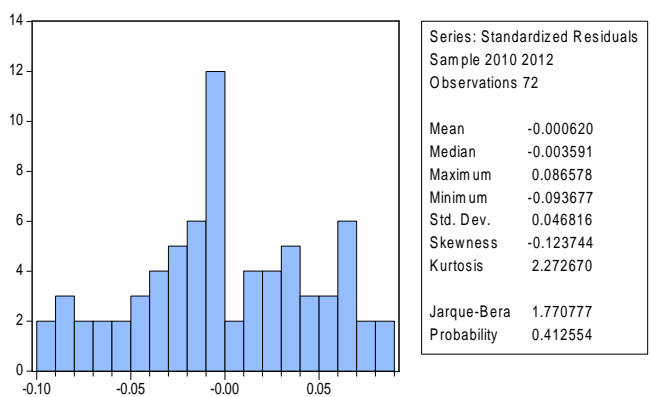

Model 3

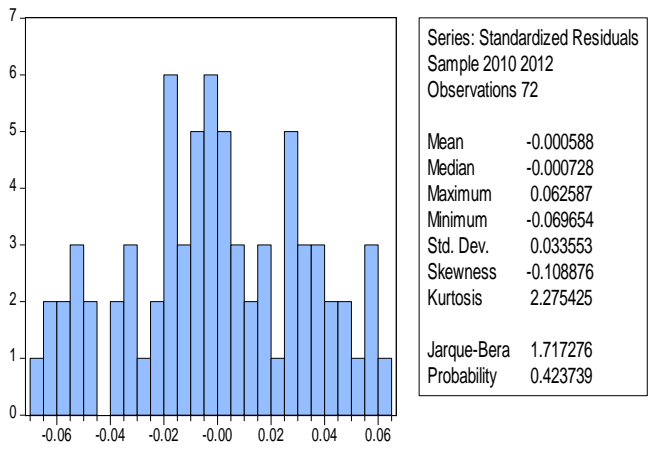

Model 2

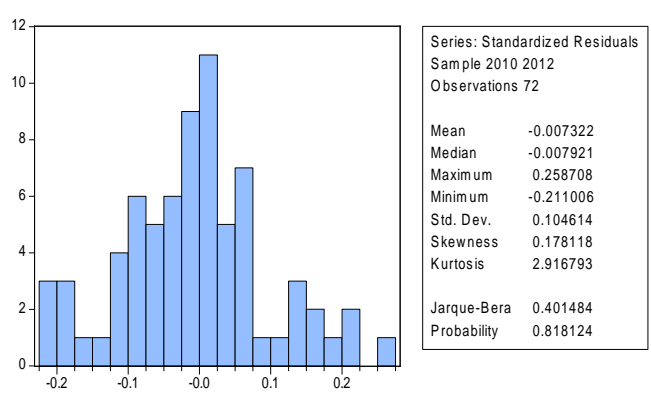

Model 4

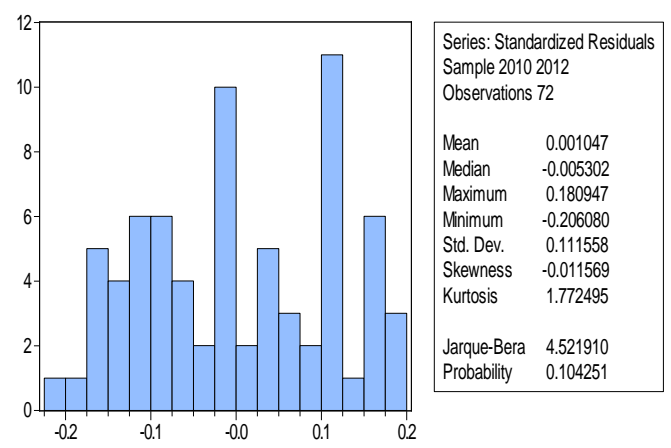

Gambar 1. Pengujian Normalitas

Salah satu cara mendeteksi ada tidaknya multikolinearitas menurut (Nachrowi dan Hardius, 2006) adalah dengan nilai tolerance adalah lebih besar dari 0.1 dan variance inflation factor (VIF) mendekati angka 1. Hasil uji VIF menurut SPSS 20 dalam tabel sebagai berikut:

Tabel 2. Hail Uji VIF

\begin{tabular}{lcc}
\hline \multicolumn{1}{c}{ Variabel } & Tolerance & VIF \\
\hline LNDEPO & 0.245 & 4.085 \\
LOANS_TA & 0.794 & 1.260 \\
LLP_TL & 0.807 & 1.239 \\
NIE_TA & 0.780 & 1.281
\end{tabular}


Widyasari dan Nataherwin: Faktor-Faktor Yang MempengaruhiKinerja...

\begin{tabular}{lcc}
\hline \multicolumn{1}{c}{ Variabel } & Tolerance & VIF \\
\hline EQUITY_TA & 0.142 & 7.054 \\
LNTA & 0.313 & 3.191
\end{tabular}

LNDEPO: kekuatan pasar, LOANS_TA: Intensitas pinjaman bank, LLP_TL: risiko, NIE_TA: kualitas manajemen, EQUITY_TA: nilai pemegang saham, LNTA: Ukuran bank

Dari tabel diatas dapat dilihat variabel eksogen dalam penelitian ini mempunyai VIF yang mendekati 1 dan tolerance yang lebih besar jauh dari 0,1 dan hanya satu variabel EQUITY_TA dan LNDEPO yang mempunyai tolerance hampir 0,1.

\section{HASIL DAN PEMBAHASAN}

Pengaruh Kekuatan pasar, intesitas pinjaman bank, ukuran bank, risiko, kualitas manajemen dan nilai pemegang saham terhadap kinerja BPR. Berikut ini tabel menyajikan hasil regresi hipotesis pertama sampai ketiga:

Tabel 3. Hasil Regresi

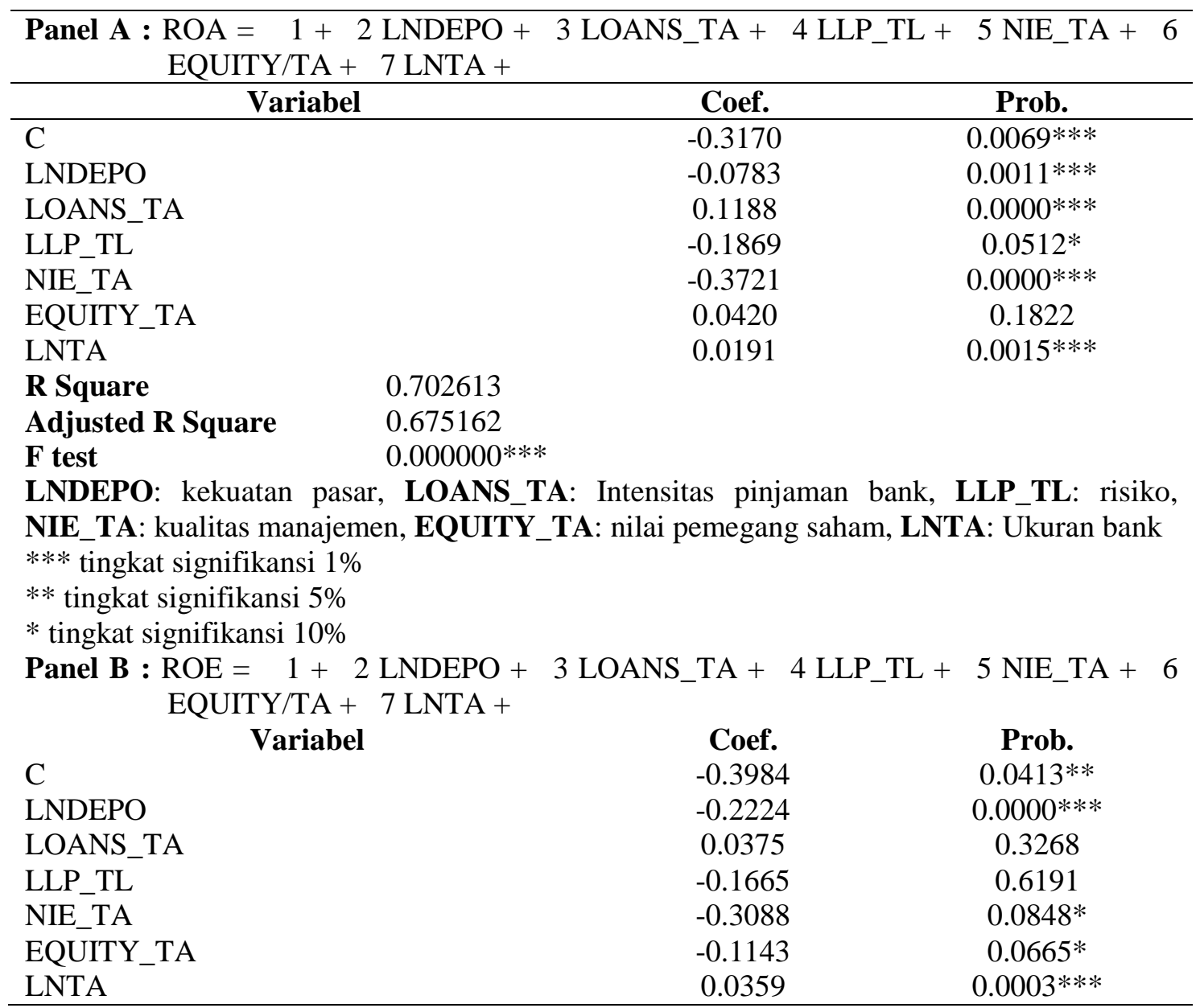




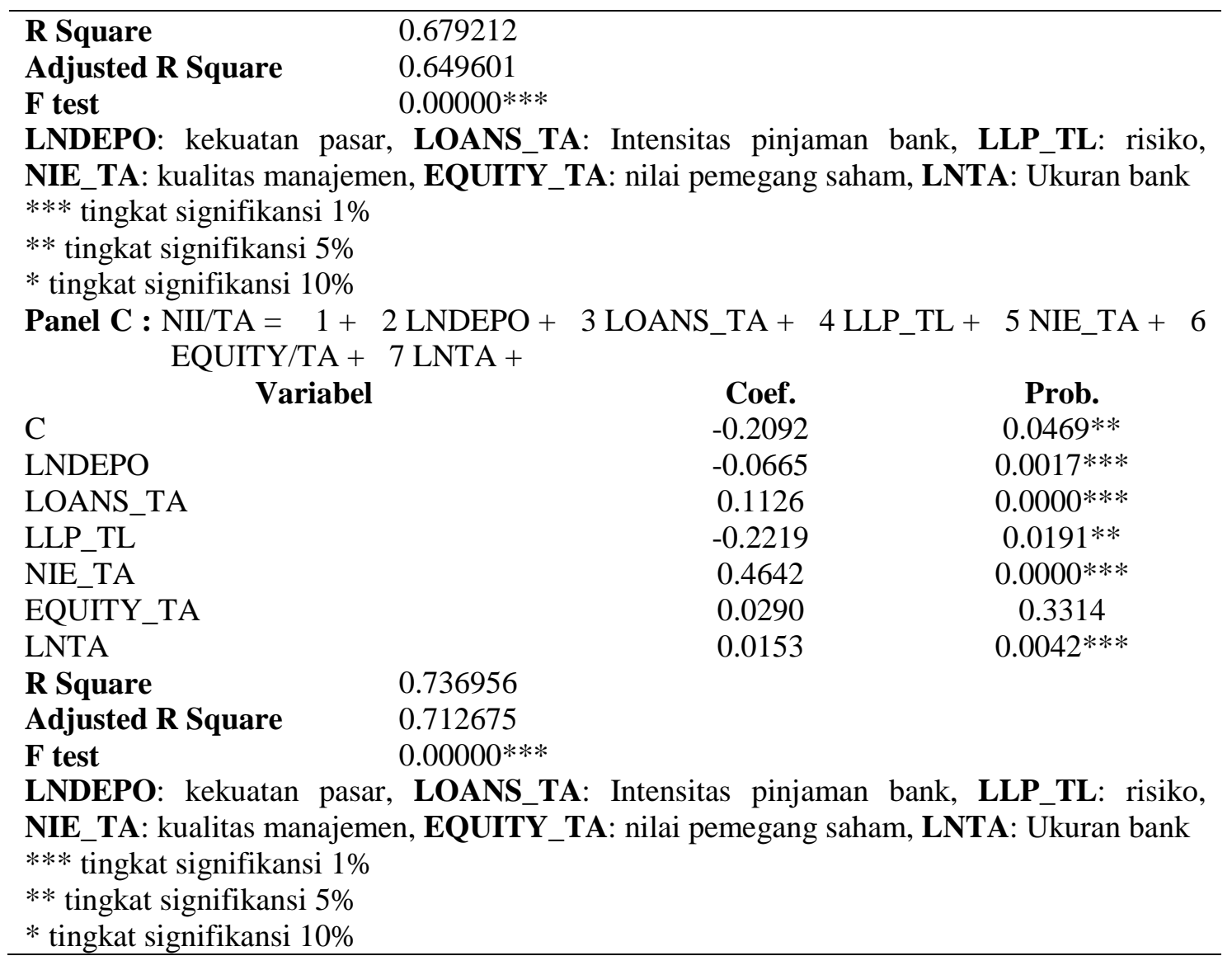

Berdasarkan Tabel 3 nilai F statistik dan Prob (F-statistic) panel A, B dan C menunjukkan nilai signifikan. Hal ini menunjukkan variabel dependen secara bersamasama dipengaruhi oleh variabel independen model tersebut. Nilai adjusted $\mathrm{R}^{2}$ digunakan untuk melihat seberapa besar variasi dari nilai variabel dependen dapat dijelaskan oleh variasi nilai dari variabel-variabel independennya. Nilai $\mathrm{R}^{2}$ untuk Panel A sebesar 67,51\%, Panel B sebesar 64,96\%, Panel C sebesar 71,27\%. Hasil tabel diatas menunjukkan : LNDEPO (kekuatan pasar) berpengaruh negatif terhadap kinerja keuangan (ROA, ROE dan NII/TA) dan signifikan pada tingkat $1 \%$. Hal ini menunjukkan bahwa kekuatan pasar yang semakin tinggi, maka kinerja keuangan akan semakin rendah, berarti semakian rendah kemampuan bank memperoleh laba. Hal ini mungkin terjadi jika suku bunga deposito meningkat sehingga menimbulkan kenaikan biaya bunga bank. Intensitas pinjaman bank (LOANS_TA) menunjukkan pengaruh yang positif dan signifikan terhadap kinerja keuangan yang diukur dengan ROA dan NII/TA, sedangkan pengaruh positif dan tidak signifikan terhadap ROE. Hal ini menunjukkan semakin tinggi bank memberikan kredit, maka semakin tinggi pula laba yang dihasilkan bank dan semakin tinggi pula pendapatan bunga yang diperoleh dari kredit tersebut. Selain itu hasil yang tidak signifikan terhadaop ROE disebabkan karena skala ROE yang berbeda dengan pengukuran intensitas pinjaman bank (LOANS_TA). Hasil pengaruh risiko bank yang diukur dengan LLP_TL terhadap kinerja keuangan (ROA dan NII/TA) menunjukkan pengaruh negatif dan signifikan, sedangkan pengaruh negatif dan tidak signifikan terhadap ROE. Hal ini sesuai dengan teori yang ada, jika bank mempunyai kredit bermasalah yang cukup tinggi, maka bank akan menanggung kerugian dari kredit yang tidak dapat ditagih, 
sehingga akan menurunkan laba. Hasil variabel kualitas manajamen (NIE_TA) yang mencerminkan biaya operasi suatu bank menunjukkan hasil yang negatif dan siginifikan terhadap ROA dan ROE, sedangkan pengaruh positif dan signifikan terhadap NII/TA. Rasio NIE_TA tinggi berdampak negatif terhadap kinerja karena bank yang efisien diharapkan dapat beroperasi dengan biaya lebih rendah. Oleh karena itu, rasio NIE_TA rendah dapat mempengaruhi kinerja positif. Sedangkan pengaruh terhadap NII/TA bahwa semakin tinggi biaya yang dihasilkan manajemen mungkin dihasilkan untuk perluasan pangsa pasar sehingga pendapatan bunga dari kredit juga semakin meningkat. Berdasarkan tabel proxy nilai pemegang saham (EQUITY_TA) mempunyai pengaruh negatif dan signifikan terhadap ROE pada tingkat $10 \%$ dan positif dan tidak signifikan terhadap ROA dan NII/TA. Hal ini menunjukkan, jika suatu bank mempunyai modal yang cenderung meningkat dari pemegang saham, cenderung mempunyai kinerja yang rendah. Selain itu menunjukkan ukuran bank mempunyai pengaruh positif dan signifikan terhadap kinerja. Hasil ini menunjukkan bahwa semakin besar suatu aset (LNTA) maka bank akan memperbesar skala bisnisnya sehingga kinerjanya dapat meningkat. Pengaruh Kekuatan pasar, intesitas pinjaman bank, ukuran bank, risiko, kualitas manajemen dan nilai pemegang saham terhadap efisiensi bank BPR.

Berikut ini tabel yang menyajikan hasil regresi hipotesis keempat:

Tabel 4. Hasil Regresi

\begin{tabular}{|c|c|c|c|}
\hline \multicolumn{4}{|c|}{$\begin{array}{l}\text { DEA }=\alpha 1+\alpha 2 \text { LNDEPO }+\alpha 3 \text { LOANS_TA }+\alpha 4 \text { LLP_TL }+\alpha 5 \text { NIE_TA }+\alpha 6 \\
\text { EQUITY } / T A+\alpha 7 \text { LNTA }+\varepsilon\end{array}$} \\
\hline \multicolumn{2}{|c|}{ Variabel } & Coef. & Prob. \\
\hline \multicolumn{2}{|l|}{$\mathrm{C}$} & 0.828 & $0.010 * * *$ \\
\hline \multicolumn{2}{|l|}{ LNDEPO } & -0.167 & $0.006 * * *$ \\
\hline \multicolumn{2}{|l|}{ LOANS_TA } & -0.299 & $0.001 * * *$ \\
\hline \multicolumn{2}{|l|}{ LLP_TL } & -0.559 & 0.113 \\
\hline \multicolumn{2}{|l|}{ NIE_TA } & -3.768 & $0.000 * * *$ \\
\hline \multicolumn{2}{|l|}{ EQŪTTY_TA } & 0.013 & 0.325 \\
\hline \multicolumn{2}{|l|}{ LNTA } & 0.036 & $0.038 * *$ \\
\hline \multicolumn{4}{|l|}{ R Square } \\
\hline \multicolumn{4}{|c|}{ Adjusted R Square $\quad 0.82748$} \\
\hline \multicolumn{4}{|c|}{ F test $\quad 0.00000 * * *$} \\
\hline \multicolumn{4}{|c|}{$\begin{array}{l}\text { LNDEPO: kekuatan pasar, LOANS_TA: Intensitas pinjaman bank, LLP_TL: } \\
\text { risiko, NIE_TA: kualitas manajemen, EQUITY_TA: nilai pemegang saham, } \\
\text { LNTA: Ukuran bank }\end{array}$} \\
\hline
\end{tabular}

Berdasarkan Tabel 4 nilai F statistik dan Prob (F-statistic) panel D menunjukkan nilai signifikan $(\mathrm{p}=0,00>0,05)$. Hal ini menunjukkan variabel dependen secara bersamasama dipengaruhi oleh variabel independen model tersebut. Nilai adjusted $\mathrm{R}^{2}$ digunakan untuk melihat seberapa besar variasi dari nilai variabel dependen dapat dijelaskan oleh variasi nilai dari variabel-variabel independennya. Nilai $\mathrm{R}^{2}$ untuk Panel D sebesar 82,75\%. Tabel 4.5 melaporkan hasil yang diperoleh dari analisis regresi. Temuan menunjukkan bahwa semua variabel penjelas signifikan secara statistik, kecuali adalah koefisien LLP_TL dan EQUITY_TA, yang secara statistik tidak signifikan. Dengan demikian, 
variabel bukan penentu signifikan dari setiap langkah efisiensi. Hasil menunjukkan bahwa hubungan kekuatan pasar (LNDEPO) terhadap efisiensi Bank BPR negatif dan siginifikan pada tingkat $1 \%$. Hal menunjukkan bahwa bank-bank lebih efisien terkait dengan bank dengan pangsa pasar lebih rendah, sehingga mengurangi argumen kepemimpinan pasar.

Proxy intesitas pinjaman bank (kredit yang diberikan), LOANS_TA, mengungkapkan hubungan negatif dan signifikan secara statistik dengan tingkat signifikansi sebesar $1 \%$. Temuan ini menyiratkan bahwa bank-bank dengan rasio pinjaman terhadap aset yang lebih tinggi cenderung memiliki skor efisiensi yang lebih rendah. Dengan demikian, pinjaman bank tampaknya dinilai lebih rendah dibandingkan bank yang alternatif output yaitu investasi, deposito, dll. (Sathye, M., 2003). Untuk proxy risiko, LLP_TL, menunjukkan adanya hubungan negatif dengan skor efisiensi yang menunjukkan peningkatan inefisiensi. Temuan ini konsisten dengan temuan sebelumnya oleh antara lain, Kwan dan Eisenbeis (1995), Resti (1997) dan Barr et al. (2002) menemukan hubungan negatif antara kredit bermasalah dan efisiensi bank. Selain itu, sebagian besar penelitian yang dilakukan menjelaskan penyebab kegagalan industri bank bahwa bank gagal menyelesaikan sebagian besar kredit bermasalah dalam keuangan mereka sebelum kegagalan itu terjadi (Barr dan Siems, 1994). Temuan ini menunjukkan bahwa manajemen mutu, yang diukur dengan NIE_TA, tampaknya memiliki dampak negatif secara konsisten dan signifikan terhadap perkiraan efisiensi. Selain itu, elastisitas efisiensi teknis sehubungan dengan NIE_TA adalah yaitu -3.768 cukup tinggi dalam kasus DEA (signifikan pada tingkat $1 \%$ ). Temuan ini seirama dengan " hipotesis manajemen yang buruk " dari Berger dan DeYoung (1997). Ukuran Rendahnya efisiensi teknis merupakan sinyal praktek manajemen yang lemah, yang berlaku untuk pengunaan input, operasi sehari-hari dan mengelola portofolio kredit. Ini berarti risiko utama yang dihadapi bank BPR di Jakarta bisa disebabkan masalah internal.

Proxy EQUITY_TA memiliki hubungan positif dengan tingkat efisiensi (tidak signifikan), yang berlawanan dengan temuan Akhigbe dan McNulty (2005). Temuan ini menunjukkan bahwa, bank lebih efisien, ceteris paribus, tidak menggunakan leverage (lebih banyak ekuitas) dibandingkan dengan perusahaan sejenis. Hasil tampaknya menunjukkan bahwa bank efisien terlibat dalam proses cenderung menambah ekuitasnya, secara sukarela atau tidak, yaitu, karena mungkin bank ingin menaikkan pendanaan, atau mungkin hanya tekanan peraturan yang mengamanatkan bank tidak berisiko jika terus menambah ekuitasnya. LNTA, sebagai proksi dari ukuran bank, menunjukkan koefisien positif dan signifikan pada tingkat $1 \%$, menunjukkan bahwa semakin besar bank, akan semakin lebih efisien bank, hal ini karena argumen skala ekonomi. Dengan demikian, asumsi terdapat kebijakan pertumbuhan baru untuk bank BPR dengan minimalisasi biaya. Secara keseluruhan pengaruh kekuatan pasar, intesitas pinjaman bank, ukuran bank, risiko, kualitas manajemen dan nilai pemegang saham terhadap efisiensi bank BPR sebesar $84,2 \%$ dengan tingkat signifikansi $1 \%$, ceteris paribus.

\section{PENUTUP}

Simpulan. Berdasarkan hasil penelitian disimpulkan bahwa hasil regresi untuk menguji pengaruh kekuatan pasar, intesitas pinjaman bank, ukuran bank, risiko, kualitas manajemen dan nilai pemegang saham secara simultan terhadap kinerja BPR sebagai berikut LNDEPO (kekuatan pasar) berpengaruh negatif terhadap kinerja keuangan (ROA, ROE dan NII/TA) dan signifikan. Intensitas pinjaman bank (LOANS_TA) menunjukkan 
pengaruh yang positif dan signifikan terhadap kinerja keuangan yang diukur dengan ROA dan NII/TA, sedangkan pengaruh positif dan tidak signifikan terhadap ROE. Hasil pengaruh risiko bank yang diukur dengan LLP_TL terhadap kinerja keuangan (ROA dan NII/TA) menunjukkan pengaruh negatif dan signifikan, sedangkan pengaruh negatif dan tidak signifikan terhadap ROE. Hasil variabel kualitas manajamen (NIE_TA) menunjukkan hasil yang negatif dan siginifikan terhadap ROA dan ROE, sedangkan pengaruh positif dan signifikan terhadap NII/TA. Rasio NIE_TA tinggi berdampak negatif terhadap kinerja bank BPR. Untuk nilai pemegang saham (EQUITY_TA) mempunyai pengaruh negatif dan signifikan terhadap ROE dan positif dan tidak signifikan terhadap ROA dan NII/TA. Secara parsial LNDEPO, LOANS_TA, NIE_TA berpengaruh negatif dan signifikan. Sedangkan LLP_TL berpengaruh negatif dan tidak signifikan. Untuk variabel EQUITY_TA berpengaruh positif dan tidak signifikan. Untuk pengaruh LNTA berpengaruh positif dan signifikan terhadap efisiensi.

Saran. Dengan menggunakan variabel lain yang mempengaruhi kinerja dan efisiensi perbankan, selain itu dalam menghitung efisiensi dapat digunakan uji non parametrik dengan menggunakan SFA (STOCHASTIC FRONTIER ANALYSIS). Serta jumlah sampel yang digunakan pada penelitian ini hanya bank BPR yang terdapat di Jakarta, sehingga pada penelitian penelitian selanjutnya dapat menambah jumlah sampel dengan berbagai karakteristik diberbagai daerah di Indonesia.

\section{DAFTAR RUJUKAN}

Akhigbe, A., and McNulty, J.E., (2005) "Profit Efficiency Sources and Differences among Small and Large U.S. Commercial Banks". Journal of Economics and Finance, 29 (3): 289-299.

Bank Indonesia, Annual Report, berbagai penerbitan

Bank Indonesia, Indonesian Financial Statistic, berbagai penerbitan.

Bank Indonesia, Siaran Pers dan Laporan Tahunan Bisnis Indonesia, 22 Juli 2003

Barr, R. dan Siems, T., (1994) Predicting Bank Failure Using DEA to Quantify Management Quality. Working Paper, Federal Reserve Bank of Dallas

Barr, R.S., Killgo, K.A., Siems, T.F. dan Zimmel, S.A., (2002) "Evaluating the Productive Efficiency and Performance of U.S. Commercial Banks". Managerial Finance, 28 (8): 3-25.

Berger, A.N. dan DeYoung, (1997) "Problem Loans and Cost Efficiency in Commercial Banks". Journal of Banking and Finance 21 (6): 849-870.

Berger, A.N dan Humphrey, D.B., (1992) Measurement and Efficiency Issues in Commercial Banking, in Z.Griliches. Measurement Issues in the Service Sectors. National Bureau of Economic Research, University of Chicago Press, hal 245-279.

Coelli, T., Prasada-Rao, D.S. dan Battese, G., (1998) An Introduction To Efficiency And Productivity Analysis. Kluwer Academic Publisher, USA.

Cooper, W.W., Seiford, L.M. and Tone, K, (2000) Data Envelopment Analysis. Kluwer Academic Publishers, Boston

Gujarati, Damodar N. dan Dawn C. Porter., (2009) Basic Econometrics. MC. Graw Hill. IMF, International Financial Statistic, berbagai penerbitan.

Institut Perbankan Indonesia. Kamus Perbankan. 1999 
Kwan, S.H. and Eisenbeis, R., (1995) “An Analysis of Inefficiencies in Banking”. Journal of Banking and Finance, 19 (3-4):733-734.

Nachrowi, D . Nachrowi dan Hardius Usman., (2006) Pendekatan Populer dan Praktis Ekonometrika. Lembaga Penerbit Fakultas Ekonomi Universitas Indonesia.

Resti, A., (1997) "Evaluating the Cost Efficiency of the Italian Banking System: What Can Be Learned from the Joint Application of Parametric and Non-Parametric Techniques". Journal of Banking and Finance 21 (2): 221-250. 